\title{
Supercritical Fluid Extraction of Bioactive Compounds from Bioresource: A Review
}

\author{
H. P. Geeta ${ }^{1^{*}}$, G. Srinivas ${ }^{2}$ and P. S. Champawat ${ }^{2}$ \\ ${ }^{1}$ Department of Processing and Food Engineering, UAS, Raichur, Karnataka, India \\ ${ }^{2}$ Department of Processing and Food Engineering, CTAE, MPUAT, \\ Udaipur, Rajasthan, India \\ *Corresponding author
}

\section{A B S T R A C T}

\begin{tabular}{l} 
Ke y w o r d s \\
$\begin{array}{l}\text { Essential oil, Triple } \\
\text { point, Green } \\
\text { technology, Waste } \\
\text { industries, Agro- } \\
\text { industries }\end{array}$ \\
\hline Article Info \\
$\begin{array}{l}\text { Accepted: } \\
\text { 07 March } 2020 \\
\text { Available Online: } \\
\text { 10 April } 2020\end{array}$ \\
\hline
\end{tabular}

The Supercritical Fluid extraction is also considered as a novel technology for extracting soluble products into a fluid from a wide range of materials using supercritical conditions of solvents. Bioactive compounds are secondary metabolites produced from a broad diversity of structures and functionalities. In the present article the potential bioresources mainly from agriculture and allied sectors have been reviewed which constitutes excellent pools for bioactive and nutraceutical compounds. These natural compounds play an important role in enhancing health, improving immunity, maintaining well being and thereby preventing as well as treating specific diseases. The present generation which is more proactive in identifying the intake of healthy food is also cautious about its processing technologies involved in it. The use of conventional solvents, thermally decomposing and unsustainable technologies in the food, pharmaceutical, and nutraceutical industries have created marketing concern for their products. Hence there is a need for cutting edge technology which can overcome these legal limitations. Supercritical Fluid Extraction (SFE) is the process of separating one component (the matrix) from another (the extractant) using supercritical fluids. The properties of the fluid (liquid and gases), under supercritical conditions, are used to extract most complex compounds. $\mathrm{CO}_{2}$ is nontoxic, inexpensive and non-flammable could be applied as a replacement for conventional solvents in an extractive process using supercritical fluid extraction process. The present paper reviews the basics of supercritical extraction technology and extraction of bioactive compounds from various agricultural and bio-resources.

\section{Introduction}

Supercritical Fluid Extraction ( $\left.\mathrm{SC}-\mathrm{CO}_{2}\right)$ has emerged as a new, additive-free, non-thermal extraction technology with a wide range of applications in the food and pharmaceutical industry. The next stage is to identify the opportunities SFE presents for the production of safe and healthy food products and ingredients. This article, in short, describes the recent findings in the applications of SFE to extract bioactive components from plant food materials, many studies indicated that SFE has significant potential for such 
applications and, thus, there is considerable opportunity for the food industry to exploit these opportunities to bring the next generation of SFE food products to the market.

Supercritical extracts proved to be of superior quality, with better functional and biological activities $^{6}$. Furthermore, studies also showed better antibacterial and antifungal properties for the supercritical product. Apart from other conventional extraction processes of bioactive compounds, more recent studies have focused on the Supercritical fluid extraction with carbon dioxide $\left(\mathrm{SFE}-\mathrm{CO}_{2}\right)$ is a promising and challenging method for the isolation of valuable essential oils and other phytochemicals with such advantages as safety and easy removal of solvent on health attributes and allergenic potential of foodstuff to develop the next generation of convenience foods. Unusual vegetable oils such as wheat germ oil, green coffee oil, rice bran oil or crude palm oil, essential oils, fatty acids, phospholipids and bioactive compounds have been extracted from fruits and vegetables using $\mathrm{SC}-\mathrm{CO}_{2}$.

Fractionation and purification are also viable applications of SFE technology in the food industry. Decaffeination of beverages such as tea and coffee, fractionation of fish oils with $\mathrm{SC}-\mathrm{CO}_{2}$ to obtain omega-3 enriched fractions is possible (Ciftci et al., 2012; Patterson, 2005)

\section{Formation of supercritical phase of $\mathrm{CO}_{2}$}

A supercritical fluid is the substance that diffuses through solids like a gas and dissolves materials like a liquid at a critical point, the point is known as supercritical point. Thus, the formation of critical phase at critical temperature and critical pressure makes the fluid as supercritical fluid. These fluids own combined properties of liquid and gases phases, as it can behave like both a liquid and a gas. The process formation of a supercritical fluid is the result of dynamic equilibrium. When a material is heated to its specific critical temperature at constant pressure in a closed system, a dynamic equilibrium is generated. This equilibrium includes the same number of molecules coming out of liquid phase togas phase by gaining energy and going into liquid phase from gas phase by losing energy. At this certain point, in the phase curve between liquid and gas, both the phases disappears and supercritical material appears.

For better understanding, the figure 1 shows the of phase diagram $\mathrm{CO}_{2}$, the colloidal areas of three phases. The phase diagram defines the temperature and pressure limits in which $\mathrm{CO}_{2}$ exits in solid liquid, gas and supercritical state. The black, blue and green line indicates the equilibrium between solid and gas, solid and liquid, liquid and gas respectively.

Whereas, the figure $2 \mathrm{a}$ shows the triple point at 5.11 bar and $-56.7{ }^{\circ} \mathrm{C}$ where system containing $\mathrm{CO}_{2}$ forms indistinguishable solid, liquid and gases phase simultaneously. Figure $2 \mathrm{~b}$ shows the existence of subcritical point of $\mathrm{CO}_{2}$, where the pressure is maintained while the temperature is taken below the supercritical threshold, causing it to become a (non-supercritical) liquid.

The liquid-gas phase boundary is called the subcritical line, as a liquid evaporating directly into a gas is called subcritical. Figure $2 \mathrm{c}$ shows the above critical point (73.8 bar and $31.1^{\circ} \mathrm{C}$ ), the liquid and gas phases cannot exist as separate phases, and $\mathrm{CO}_{2}$ develops supercritical properties, where it has some characteristics of a gas and others of a liquid.

Typically, supercritical fluid extraction using $\mathrm{CO}_{2}$ involves the uses of specialized extraction unit which lowers the temperature 
and compresses the $\mathrm{CO}_{2}$ until it reaches liquefied stage, this liquefied $\mathrm{CO}_{2}$ gas passes through food material to pullout the target component concentrates. After the successful extraction process, the $\mathrm{CO}_{2}$ depressurized to allow it to turn from liquid into gas. The $\mathrm{CO}_{2}$ obtained at the end is either reused or released it into environment safely making it green extraction technology with no harmful footprints to nature.

\section{Supercritical fluid extraction process}

The extraction process using SFE technology contains 3 main processes, as shown in the figure 3 .

\section{Pumping process}

From $\mathrm{CO}_{2}$ Cylinder, the $\mathrm{CO}_{2}$ is usually pumped at about 50 bar and at temperature below $5^{\circ} \mathrm{C}$ to maintain liquid conditions. Usually, the pump used in the system is for compressing the fluid rather than pumping operation. Reciprocating $\mathrm{CO}_{2}$ pumps or syringe pumps are often used for small scale extraction whereas, for large scale diaphragm pumps are mostly used.

The pressure in the system is maintained from the pump right through the pressure vessel by using simple regulator or back pressure regulator.

\section{Preheating process}

After Pressurization, the liquid $\left(\mathrm{CO}_{2}\right)$ is pumped to a heating zone, where it is heated to supercritical conditions, thus preheating prevents excessive cooling. Electrically heated restrictors are used for this purpose.

\section{Extraction process}

A pressure cell to contain the sample, a means of maintained pressure in the system and a sample collecting vessel. The $\mathrm{CO}_{2}$ under supercritical condition is then passes into the extraction vessel, where it rapidly diffuses into the solid matrix and dissolves the material to be extracted.

The dissolved material is swept from the extraction cell into a separator at lower pressure, and the extracted material settles out. The supercritical fluid can then be cooled, re compressed and recycled (Ayre et al., 2013; Sapkale, et al., 2010) .

\section{Optimization of SFE process}

The main aim of optimization is to increase the yield, reduce the input cost and duration of extraction. Using Response Surface Methodology (RSM) optimization of extraction cycle is carried out, where maintenance of pressure, temperature, and solvent flow rate and time duration of operation is optimized. On other hand the main objective of optimization of SFE- $\mathrm{CO}_{2}$ process is to maximizing diffusion and solubility.

\section{Maximizing diffusivity}

Diffusivity of $\mathrm{CO}_{2}$ into sample matrix can be achieved by reducing the particle size, increasing the temperature or swelling the matrix (this can be increased by increasing the solvent pressure or by adding co-solvents).

\section{Maximizing solubility}

Solubility of extracted components into $\mathrm{CO}_{2}$ can be achieved by increasing the pressure and decreasing the pressure within the critical temperature and pressure. Further, Solubility can be also increased by adding co-solvent such as methanol and ethanol which adds more polar compounds along with the solvent $\mathrm{CO}_{2}$. 


\section{Table.1}

\begin{tabular}{|c|c|c|c|c|c|c|c|}
\hline \multirow{2}{*}{$\begin{array}{l}\text { Bioactive } \\
\text { compounds }\end{array}$} & \multirow[t]{2}{*}{ Material } & \multicolumn{4}{|c|}{ Extraction condition } & \multirow[t]{2}{*}{ Target compound } & \multirow[t]{2}{*}{ Reference } \\
\hline & & $\begin{array}{c}\text { Temperature } \\
\left({ }^{\circ} \mathrm{C}\right)\end{array}$ & $\begin{array}{c}\text { Pressure } \\
\text { (bars) }\end{array}$ & $\begin{array}{l}\text { Time } \\
(\mathbf{m i n})\end{array}$ & $\begin{array}{c}\text { Flow rate } \\
(\mathrm{g} / \mathrm{min})\end{array}$ & & \\
\hline \multirow{4}{*}{$\begin{array}{l}\text { Fruits and } \\
\text { Vegetable } \\
\text { processing } \\
\text { Industries }\end{array}$} & Apple pomace & 80 & 300 & & & Total triterpenic content $(9.6$ mg/g) & Ferrentino et al., 2018 \\
\hline & Citrus fruits & $\begin{array}{l}40-60 \\
30-60 \\
28-60\end{array}$ & $\begin{array}{c}85-200 \\
100-300 \\
80-150\end{array}$ & $\begin{array}{l}360 \\
120\end{array}$ & $\begin{array}{l}3(\mathrm{ml} / \mathrm{min}) \\
16(\mathrm{~g} / \mathrm{min})\end{array}$ & $\begin{array}{c}\text { Volatile compounds } \\
\text { Volatile compounds }(90-92.5 \%) \text { and Limonene } \\
(74-78 \%) \\
\text { Essential oil }(3.4-4 \%)\end{array}$ & $\begin{array}{l}\text { Jerkovic et al., } 2016 \quad \text { Jokic et al., } \\
2016 \\
\text { Roy } \text { et al., } 2007 \\
\text { Nautiyal and Tiwari } 2014\end{array}$ \\
\hline & $\begin{array}{l}\text { Tomato } \\
\text { Tomato peels }\end{array}$ & $\begin{array}{c}80 \\
50-80\end{array}$ & $\begin{array}{c}275 \\
300-500\end{array}$ & 105 & $\begin{array}{l}8(\mathrm{ml} / \mathrm{min}) \\
3-6(\mathrm{~g} / \mathrm{min})\end{array}$ & $\begin{array}{c}\text { Lycopene }(82.5 \%) \\
\text { Lycopene }(86 \%) \\
\text { Lycopene }(32-60 \%) \text { and } \\
\square \text { - carotene }(28-59 \%)\end{array}$ & $\begin{array}{l}\text { Malik et al., } 2015 \\
\text { Kehili et al., } 2017 \\
\text { Nobre et al., } 2012\end{array}$ \\
\hline & $\begin{array}{l}\text { Apricot } \\
\text { Pumpkin } \\
\text { Peach } \\
\text { Green pepper } \\
\text { Yellow pepper } \\
\text { Red pepper }\end{array}$ & $59{ }^{\circ} \mathrm{C}$ & 300 & 30 & 15 & $\begin{array}{ccc}\square \text { - carotene } & \text { Lutein } & \text { Lycopene }(\%) \\
98.7 & 79.9 & - \\
92.4 & - & 87.4 \\
99.8 & - & - \\
98.6 & 99.8 & - \\
99.8 & 99.6 & - \\
- & 98.1 & \end{array}$ & Lima et al., 2013 \\
\hline Seed materials & $\begin{array}{l}\text { Hemp, } \\
\text { Passion seed, } \\
\text { chia, } \\
\text { canola }\end{array}$ & $\begin{array}{l}40-60 \\
40-60 \\
40-80 \\
40-60\end{array}$ & $\begin{array}{l}300-400 \\
150-250 \\
136-408 \\
200-250\end{array}$ & & & Oil & $\begin{array}{l}\text { Aladic et al., 2011; Cardoso et al., } \\
\text { 2013, } \\
\text { Uribe et al., 2011; Pederssetti } \text { et al., } \\
2011\end{array}$ \\
\hline $\begin{array}{l}\text { Oleoresin } \\
\text { Industries }\end{array}$ & $\begin{array}{l}\text { Capsicum spp } \\
\text { Ginger, } \\
\text { Horsetail } \\
\text { Turmeric }\end{array}$ & $\begin{array}{c}31-35 \\
25-35 \\
30,40 \\
50\end{array}$ & $\begin{array}{c}74 \\
200-250 \\
120-300 \\
250\end{array}$ & 90 & $3 \mathrm{ml} / \mathrm{min}$ & $\begin{array}{c}\text { Capsithin } \\
\text { Gingerin } \\
\text { Methenolone, phytosteriod } \\
\text { Curcumin (1.69) }\end{array}$ & $\begin{array}{l}\text { Guimar et al., } 2017 \\
\text { Zancan } \text { et al., } 2002 \\
\text { Michielina } \text { et al., } 2005 \\
\text { Radzali } \text { et al., } 2016\end{array}$ \\
\hline $\begin{array}{c}\text { Herbal } \\
\text { Industries }\end{array}$ & $\begin{array}{l}\text { Aleo vera } \\
\text { Basil } \\
\text { Noni } \\
\text { Rosemerry }\end{array}$ & $\begin{array}{c}45.91 \\
40 \\
37 \\
50\end{array}$ & $\begin{array}{l}320 \\
400 \\
210 \\
180\end{array}$ & $\begin{array}{c}140 \\
- \\
104 \\
-\end{array}$ & $\begin{array}{l}0.84 \mathrm{ml} / \mathrm{min} \\
1.6 \mathrm{~g} / \mathrm{min} \\
20 \mathrm{~L} / \mathrm{min} \\
1 \mathrm{~g} / \mathrm{min}\end{array}$ & $\begin{array}{c}\alpha \text { - tocopherol }(53.41 \%) \\
\text { essential oil }(2.2 \%) \\
\text { Essential oil }(20.13 \%) \\
\text { pentacyclic triterpenes }(45.22 \%)\end{array}$ & $\begin{array}{l}\text { Bashipour and Ghoreishi, } 2015 \\
\text { Coelho } \text { et al., } 2018 \\
\text { Bai } \text { et al } 2012 \\
\text { Bensebia } \text { et al., } 2016\end{array}$ \\
\hline $\begin{array}{l}\text { Agro-Waste } \\
\text { Industries }\end{array}$ & $\begin{array}{l}\text { Spent coffee } \\
\text { Corn biomass } \\
\text { Silkworm Pupae } \\
\text { Tobacco }\end{array}$ & $\begin{array}{c}40 \\
118 \\
45 \\
40\end{array}$ & $\begin{array}{l}250 \\
200 \\
203 \\
300\end{array}$ & $\begin{array}{l}40 \\
25-30 \\
145 \\
5\end{array}$ & $\begin{array}{l}100 \mathrm{~g} / \mathrm{min} \\
4 \mathrm{~g} / \mathrm{min} \\
24 \mathrm{~g} / \mathrm{min} \\
1 \mathrm{l} / \mathrm{min}\end{array}$ & $\begin{array}{c}\text { Biodiesel } \\
\text { Lignin }(9.20 \%) \\
\text { Oil }(30 \%) \\
\text { Solanesol }(0.44 \%)\end{array}$ & $\begin{array}{l}\text { Paiva, } 2015 \\
\text { Neata } \text { et al., } 2015 \\
\text { Srinivas et al., } 2019 \\
\text { Ruiz-Rodriguez et al } 2008\end{array}$ \\
\hline $\begin{array}{c}\text { Marine } \\
\text { Industries }\end{array}$ & $\begin{array}{l}\text { Whole Fish } \\
\text { Shrimps } \\
\text { Marine micro algae }\end{array}$ & $\begin{array}{c}40-80 \\
56.88 \\
40\end{array}$ & $\begin{array}{c}250-400 \\
215.68 \\
500\end{array}$ & $\begin{array}{c}300 \\
120 \\
300-810\end{array}$ & $\begin{array}{c}2 \mathrm{ml} / \mathrm{min} \\
1.89 \mathrm{ml} / \mathrm{min} \\
33.33 \mathrm{~g} / \mathrm{min}\end{array}$ & $\begin{array}{c}\text { Fish Oil }(10-50 \%) \\
\text { Astaxanthin }(58.50 \mu \mathrm{g} / \mathrm{g}) \\
\text { Polyphenol }(20 \mathrm{mg} / \mathrm{g}) \text { and other macro and } \\
\text { micro elements }\end{array}$ & $\begin{array}{l}\text { Ivanovs \& Blumberga } 2017 . \\
\text { Radzali } \text { et al., } 2016 \\
\text { Michalak } \text { et al., } 2016\end{array}$ \\
\hline $\begin{array}{l}\text { Brewery } \\
\text { Industries }\end{array}$ & $\begin{array}{l}\text { Cabernet Sauvignon } \\
\text { Green Tea } \\
\text { Coffea Arabica } \\
\text { Hops }\end{array}$ & $\begin{array}{l}35 \\
60 \\
70 \\
50\end{array}$ & $\begin{array}{l}180 \\
250 \\
200 \\
300\end{array}$ & $\begin{array}{c}- \\
- \\
180 \\
360\end{array}$ & $\begin{array}{c}0.5 \mathrm{ml} / \mathrm{min} \\
10 \mathrm{~g} / \mathrm{min} \\
5 \mathrm{~g} / \mathrm{min} \\
-\end{array}$ & $\begin{array}{c}\text { Phenolic (14\%) } \\
\text { Caffine (1.8\%) and Catechins (2.7\%) } \\
\text { Cafestol (85\%) Kahweol (80\%) } \\
\alpha \text {-acids (41\%), } \beta \text {-acids (19.5\%). }\end{array}$ & $\begin{array}{l}\text { Silva } \text { et al., } 2017 \\
\text { Sokmen } \text { et al., } 2018 \\
\text { Oliveira } \text { et al., } 2014 \\
\text { Roj et al., } 2015\end{array}$ \\
\hline
\end{tabular}


Fig.1 Three phase diagram of $\mathrm{CO}_{2}$

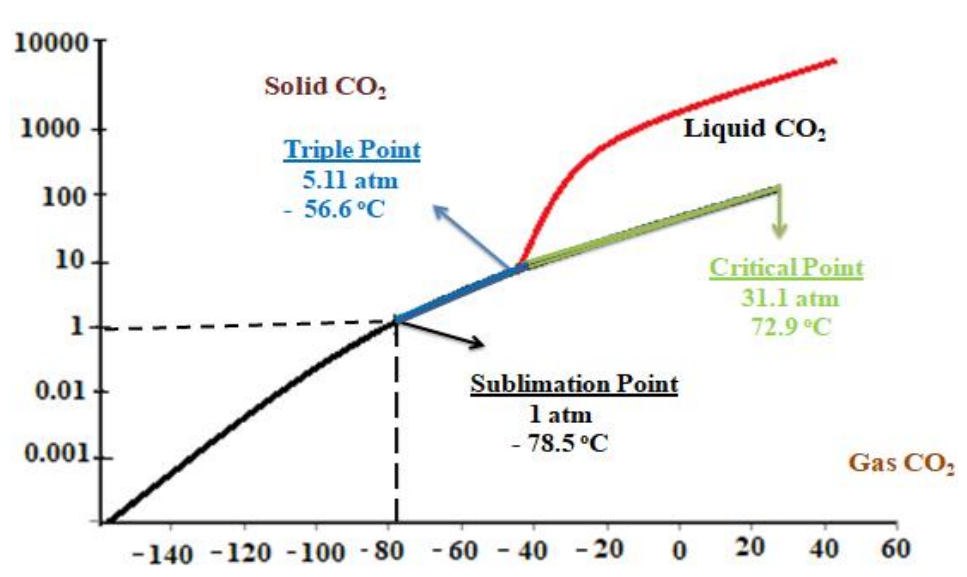

Fig.2

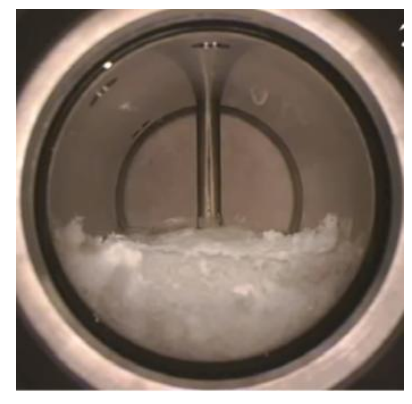

a Triple point of $\mathrm{CO}_{2}$

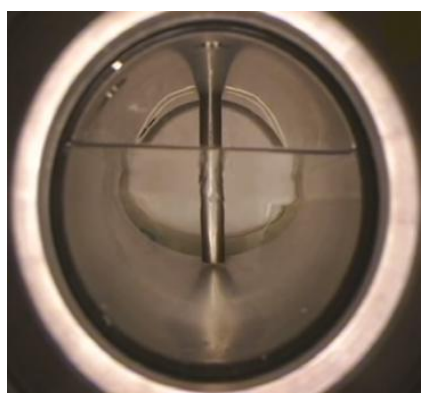

2b. Subcritical point of $\mathrm{CO}_{2}$

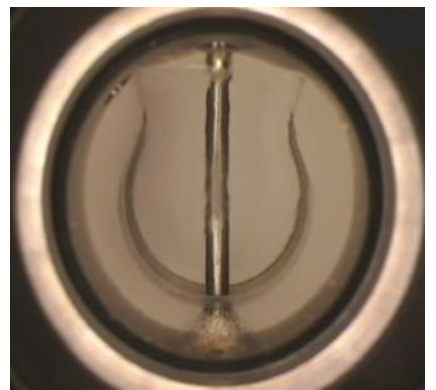

2c. Supercritical Point of $\mathrm{CO}_{2}$

Fig.3 Overview setup of supercritical fluid extraction $\left(\mathrm{SC}-\mathrm{CO}_{2}\right)$

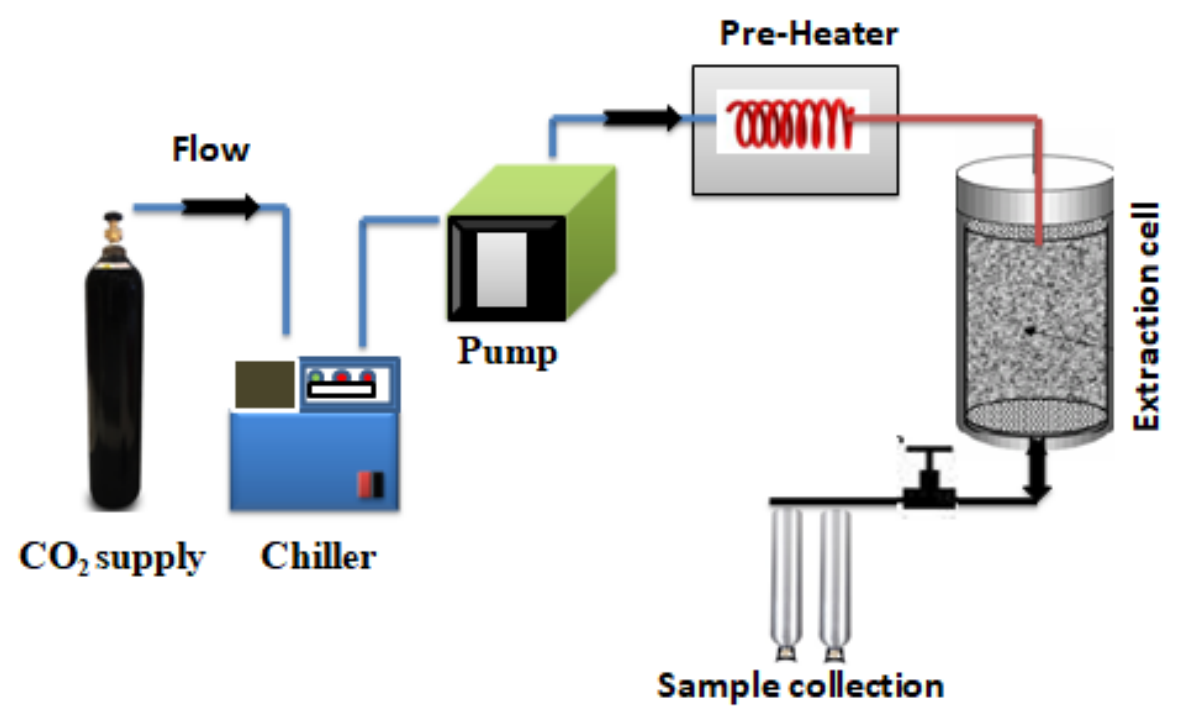


SFE technology in extracting bioactive compounds

Demand for secondary metabolites recovery from plant food materials and their byproducts is increasing due to their nutraceutical properties and other health benefits. Biologically active compounds of medicinal herbs (antioxidants), essential oils (volatile compounds), nutraceuticals and pharmaceuticals (lycopene, astaxanthin, hyperforin etc.), seed oils (tocopherols etc.), oleoresins from spices, and natural colours (carotene, chlorophyll) etc. (Table 1) Shows some of the recent findings on the extraction of bioactive compounds using SFE- $\mathrm{CO}_{2}$ from different bio resource.

In conclusion supercritical fluid extraction $\left(\mathrm{SC}-\mathrm{CO}_{2}\right)$ has captured considerable attention in various food and pharmaceutical industries due to safe and quality product output. With a green and efficient technology, it is finding its wider application beyond the extraction process. It has become complimentary technology which can significantly widen the ambit of the products both sourced from animal and plants to be extracted. Owning expeditious advantages supercritical fluid extraction $\left(\mathrm{SC}-\mathrm{CO}_{2}\right)$ can be next generation extraction technology with huge potential and thus merits further investigation.

\section{References}

Aladic, K., Jarni, K., Barbir, T., Vidovic, S., Vladic, J., Bilic, M. and Jokic, S. 2011. Supercritical $\mathrm{CO}_{2}$ extraction of hemp (Cannabis sativa L.) seed oil. Ind. Crops Prod. 76: 472-478.

Ayre, A., Ghude, K., Mane, P., Nemade, M., Gosavi, S., Pathare, A. and Lad, A. 2013. Supercritical Fluid Extraction-A Green Paradigm in the Area of Separation Science. Asian J. of Biomedical and Pharmaceutical Sci.
23: 1-7.

Bai, X, P., Zhao, X., Guo, Z., Liu, X and Xu, F. 2012. Optimization of Supercritical $\mathrm{CO}_{2}$ Extraction of Noni (Morinda citrifolia L) Seed Oil Using Response Surface Methodology", Advanced Materials Res. 743-747.

Bashipour, F. and Ghoreishi, S. M. 2015. Response Surface optimization of supercritical $\mathrm{CO}_{2}$ Extraction of $\alpha-$ tocopherol from gel and skin of Aloe Vera and almond leaves. J. Supercritical Fluids 95: 348-354.

Bensebia, B., Benseber, B., Alliya, $\mathrm{K}$ and Barth, D. 2016. Supercritical $\mathrm{CO}_{2}$ extraction of triterpenes from rosemary leaves: Kinetics and modeling, J. Separation Sci. and Tech. 13: 2174-2182.

Cardoso De, R., Rossi, R. M., Gimenes, M. L., Jagadevan, S., Machado, G, W., and Davantel De Ba, S. T. 2013. Extraction of passion fruit seed oil using supercritical $\mathrm{CO}_{2}$ : a study of mass transfer and rheological property by Bayesian inference. Grasas Aceites 64: 400-406

Ciftci, O. N., Roman, P. and Magdalena, R. 2012. Lipid components of flax, perilla, and chia seeds. European J. of Lipid Sci. and Tech. 114

Coelho, J., Jerson, V., Karmali, A., Nicolai, M., Reis, C. P., Nobre, B. and Palavra, A. 2018. Supercritical $\mathrm{CO}_{2}$ Extracts and Volatile Oil of Basil (Ocimum basilicum L.) Comparison with Conventional Methods. Separations 5: 21.

Lima, M., Kestekoglou, I., Charalampopoulos, D. and Chatzifragkou, A. 2013. Supercritical fluid extraction of carotenoids from vegetable waste matrices. Molecules, 3

Ferrentino, G., Morozova, K., Mosibo, K.O., Ramezani, M. and Scampicchio, M. 
2018. Bio-recovery of antioxidants from apple pomace by supercritical fluid extraction. J. clean production. 253-261.

Guiomar M., Alan, J, H., Maribel, J. F. and Azuara, E. 2017. Oleoresin from capsicum spp.: Extraction methods and bioactivity. Food Bioprocess Tech. 10: 51-76

Ivanovs, K. and Blumberga, D. 2017. Extraction of fish oil using green extraction methods: a short review. International Scientific Conference "Environmental and Climate Technologies", CONECT 2017, 10-12 May 2017, Riga, Latvia. Energy Procedia. 128: 477-483.

Jerkovic, I., Druzic, J., Marijanovic, Z., Gugic, M., Jokic, S. and Roje, M. 2015. GC-FID/MS profiling of supercritical $\mathrm{CO}_{2}$ extracts of peels from Citrus aurantium, C. sinensis cv. Washington navel, C. sinensis cv. Tarocco and C. sinensis cv. Doppio Sanguigno from Dubrovnik Area (Croatia). Natural Product Communications, 7: 1315-1318.

Jokic, S., Bijuk, M., Aladic, K., Bilic, M. and Molnar, M. 2016. Optimization of supercritical $\mathrm{CO}_{2}$ extraction of grape seed oil using response surface methodology. Int. J. Fd. Sci. Tech. 51: 403-410.

Kehili, M., Kammlott, M., Choura, S., Zammel, A., Zetzl, C., Smirnova, I., Allouched, N. and Sayadi, S. 2017. Supercritical $\mathrm{CO}_{2}$ extraction and antioxidant activity of lycopene and $\square$-carotene-enriched oleoresin from tomato (Lycopersicum esculentum L.) peels by-product of a Tunisian industry. Fd. bio-products processing. 102: 340-349

Malik S. Y., Haddadin, Jamal and S. H. 2015. Lycopene Extraction from Tomato Pomace with Supercritical Carbon
Dioxide: Effect of Pressures, Temperatures and $\mathrm{CO}_{2}$ Flow Rates and Evaluation of Antioxidant Activity and Stability of Lycopene. Pakistan J. Nutn. 14: 942-956.

Michalak, I., Gorka, B. Wieczorek, P. P., Edward R, L, J., Lęska, B., Beata, M, R, W., Grzegorz, S., Agnieszka, D. and Katarzyna, C. 2016. Supercritical fluid extraction of algae enhances levels of biologically active compounds promoting plant growth, European J. Phycology. 3: 243-252.

Michielina, M. Z. E., Louisiane, F. V., Brescianib, D. L., Yunesb, R, A., Sandra R. S. F. 2005. Composition profile of horsetail (Equisetum giganteum L.) oleoresin: comparing SFE and organic solvents extraction. J. of Supercritical Fluids. 33: 131-138

Nautiyal, O. H., Tiwari, K. K. 2014. Supercritical and subcritical carbon dioxide extraction of Indian orange peel oil. A Chemical Tech. 1: 8-15

Neata, G., Campeanu, G., Popescu, M., Popa, O., Babeanu, N., Basaraba, N. and Popescu, D. 2015 Lignin Extraction from Corn Biomass. Romanian Biotechnological Letters. 20: 1040610412.

Nobre, B. P., Gouveia, L., Patricia, G. Matos, S., Cristino, A. F., Palavra, A. F. and Mendes R. L. 2012. Supercritical Extraction of Lycopene from Tomato Industrial Wastes with Ethane. Molecules 17: 8397-8407

Oliveira, P. M. A., Almeidaa, R. H., Oliveiraa, N. A., Gonc, S. B. C. and alves a, Oliveira, A. L. 2014. Enrichment of diterpenes in green coffee oil using supercritical fluid extraction - Characterization and comparison with green coffee oil from pressing. J. Supercritical Fluids. 95: $137-145$

Patterson, C, A. 2005. Supercritical Fluid 
Extraction: An upcoming green technology. Tech. Watch.1: 1-12.

Paiva. 2015. Valorization of agro-industrial waste, Sandra da Fonseca, Abrantes.https://pdfs.semanticscholar. org/c39e/c2f1fc7ebb63515fa01ad0197 d8df30135bf.pdf

Pederssetti, M. M., Palu, F., da Silva, E. A., Rohling, J. H., Cardozo-Filho, L.and Dariva, C. 2011. Extraction of canola seed (Brassica napus) oil using compressed propane and supercritical carbon dioxide. J. Fd. Engg. 102: 189196.

Radzali, S. A., Masturah M., Baharin, B. S., Rashidi O. and Rahman, R. A. 2016. Optimization of Supercritical Fluid Extraction of astaxanthin from Penaeus monodon waste using ethanol-modified carbon dioxide. J. Engg. Sci. Tech. 11: 722 - 736 .

Roj, E., Vanja M., Tadic, Misic, M., Zizovic, I., Arsic, I., Dobrzynska-Inger, A., and Kostrzewa, D. 2015 Supercritical carbon dioxide hops extracts with antimicrobial properties. De Gruyter Open 13: 1157-1171.

Roy, B. C., Munehiro, H., Hiro U., Mitsuru, S. and Motonobu, G. 2007. Supercritical Carbon Dioxide Extraction of the Volatiles from the Peel of Japanese Citrus Fruits. J. Essential Oil Res. 19: 78-84.

Ruiz-Rodriguez, A., Bronze, M. R and da Ponte, M. N. 2008. Supercritical fluid extraction of tobacco leaves: A preliminary study on the extraction of solanesol.
J. Supercrit. Fluids 45: 171-176.

Sapkale, G, N., Patil, S. M., Surwase, U.S. and Bhatbhage, P. K. 2010. Supercritical fluid extraction: Review. Int. J. Chem. Sci.: 8: 729-743.

Silva, W., Romero, J., Morales, E., Melo. and Mendoz, M. 2017. Red wine extract obtained by membrane-based supercritical fluid extraction: Preliminary characterization of chemical properties. Brazil J Cheml. Engg. 34: 567-581.

Sokmen, M., Demir, E., Yousuf, S. 2018. Optimization of sequential supercritical fluid extraction (SFE) of caffeine and catechins from green tea. J. Supercritical Fluids. https://doi.org/10.1016/j.supflu.2017.0 9.027

Srinivas, G., Udaykumar, N., Ramachandra, C. T., Ramappa, K. T and Ashoka, J. 2019. Supercritical fluid extraction of pupae oil from mulberry silkworm (Bombyx mori L.) J. Pharmacognosy and Phytochemistry. 8: 4507-4513

Uribe, J. A. R., Perez, J. I. N., Kauil, H. C., Rubio, G. R. and Alcocer, C. G. 2011 Extraction of oil from chia seeds with supercritical $\mathrm{CO}_{2}$. J. Supercritical Fluids, 56: 174-178.

Zancan, K. C., Marques, M. O. M., Petenate, A. J and Meireles, M. A. A. 2002. Extraction of ginger (Zingiber officinale Roscoe) oleoresin with $\mathrm{CO}_{2}$ and co-solvents: A study of the antioxidant action of the extracts. J. Supercritical Fluids. 57-76.

\section{How to cite this article:}

Geeta, H. P., G. Srinivas and Champawat, P. S. 2020. Supercritical Fluid Extraction of Bioactive Compounds from Bioresource: A Review. Int.J.Curr.Microbiol.App.Sci. 9(04): 559566. doi: https://doi.org/10.20546/ijcmas.2020.904.068 